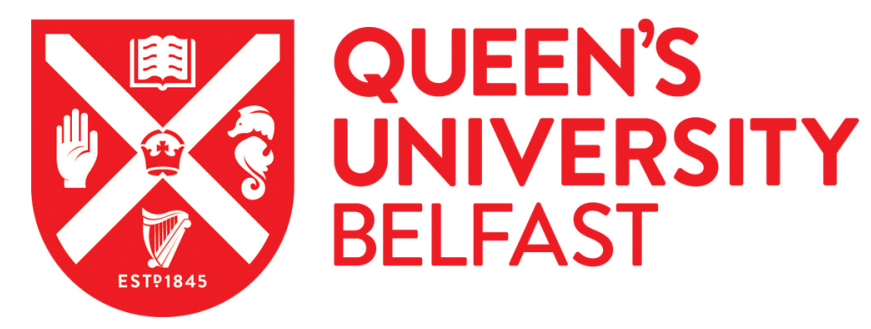

\title{
Late Holocene marine radiocarbon reservoir correction for the south and east coast of South Africa
}

Maboya, M. L., Meadows, M. E., Reimer, P. J., Backeberg, B. C., \& Haberzettl, T. (2018). Late Holocene marine radiocarbon reservoir correction for the south and east coast of South Africa. Radiocarbon Journal, 60(2), 571582. https://doi.org/10.1017/RDC.2017.139

Published in:

Radiocarbon Journal

Document Version:

Peer reviewed version

Queen's University Belfast - Research Portal:

Link to publication record in Queen's University Belfast Research Portal

Publisher rights

(๖) 2017 by the Arizona Board of Regents on behalf of the University of Arizona. This work is made available online in accordance with the publisher's policies. Please refer to any applicable terms of use of the publisher.

\section{General rights}

Copyright for the publications made accessible via the Queen's University Belfast Research Portal is retained by the author(s) and / or other copyright owners and it is a condition of accessing these publications that users recognise and abide by the legal requirements associated with these rights.

Take down policy

The Research Portal is Queen's institutional repository that provides access to Queen's research output. Every effort has been made to ensure that content in the Research Portal does not infringe any person's rights, or applicable UK laws. If you discover content in the Research Portal that you believe breaches copyright or violates any law, please contact openaccess@qub.ac.uk. 


\section{RADIOCARBON}

\section{四国 CAMBRIDGE

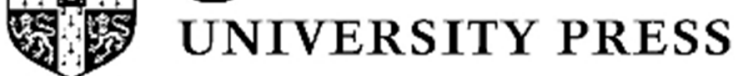

\section{Late Holocene marine radiocarbon reservoir correction for the south and east coast of South Africa}

\begin{tabular}{|r|l|}
\hline Journal: & Radiocarbon \\
\hline Manuscript ID & RDC-RES-2017-0040.R1 \\
\hline Manuscript Type: & Research Article \\
\hline Date Submitted by the Author: & $17-$ Oct-2017 \\
\hline Complete List of Authors: & $\begin{array}{l}\text { Maboya, Matjie; University of Cape Town, Environmental and Geographical } \\
\text { Sciences; Friedrich Schiller University Jena, Physical Geography } \\
\text { Meadows, Michael; University of Cape Town, Environmental and } \\
\text { Geographical Sciences; East China Normal University, School of Geographic } \\
\text { Sciences } \\
\text { Reimer, Paula; Queens University Belfast, Geography, Archaeology and } \\
\text { Palaeoecology; Centre for Climate, the Environment and Chronology } \\
\text { (14CHRONO), School of Natural and Built Environment, Queen's University } \\
\text { Belfast } \\
\text { Backeberg, Björn; Council for Scientific and Industrial Research, Coastal } \\
\text { Systems, Natural Resources and the Environment; Nansen-Tutu Centre for } \\
\text { Marine Environmental Research, University of Cape Town; Nansen } \\
\text { Environmental and Remote Sensing Center, University of Bergen } \\
\text { Haberzettl, Torsten; Friedrich Schiller University Jena, Physical Geography }\end{array}$ \\
\hline Keywords: & $\begin{array}{l}\text { Chronology, Radiocarbon dating, Marine Reservoir Effect, Reservoir } \\
\text { correction, South Africa }\end{array}$ \\
\hline & \\
\hline
\end{tabular}

\section{SCHOLARONE}

Manuscripts 


\title{
Late Holocene marine radiocarbon reservoir correction for the south and east coast of South Africa
}

Matjie L Maboyaa, ${ }^{a *}$, Michael E Meadows ${ }^{a, e}$, Paula J Reimer ${ }^{c, d}$, Björn C Backeberg ${ }^{\mathrm{f}, \mathrm{g}, \mathrm{h}}$ and Torsten Haberzettl ${ }^{\mathrm{b}}$

\author{
Author Addresses \\ a) Department of Environmental \& Geographical Science, University of Cape Town, Private \\ Bag X3, Rondebosch 7701, South Africa \\ b) Physical Geography, Institute of Geography, Friedrich Schiller University Jena, \\ Löbdergraben 32, 07743 Jena, Germany \\ c) School of Natural and Built Environment, Queen's University Belfast, Belfast BT7 1NN, \\ United Kingdom \\ d) Centre for Climate, the Environment \& Chronology (14CHRONO), School of Natural and \\ Built Environment, Queen's University Belfast, Belfast BT7 1NN, United Kingdom \\ e) School of Geographic Sciences, East China Normal University, 500 Dongchuan Road, \\ Shanghai 200241, China \\ f) Coastal Systems, Natural Resources and the Environment, Council for Scientific and \\ Industrial Research (CSIR), Jan Celliers Road, Stellenbosch 7600, South Africa \\ g) Nansen-Tutu Centre for Marine Environmental Research, University of Cape Town, \\ Private Bag X3, Rondebosch 7701, South Africa \\ h) Nansen Environmental and Remote Sensing Center, Thormøhlens 47, 5006, Bergen, \\ Norway
}

*Corresponding Author: Matjie L Maboya mmaboya09@alaalumni.org

\section{ABSTRACT}

The marine reservoir effect is the difference in radiocarbon $\left({ }^{14} \mathrm{C}\right)$ between the atmosphere and the marine surface ocean. In order to overcome the dating errors induced, it is necessary to correct marine radiocarbon ages for this effect. $\Delta R$ is the difference between the marine ${ }^{14} \mathrm{C}$ age and the marine calibration curve based on an ocean-atmosphere box diffusion model which accounts for the time delay in diffusion of carbon into the ocean from the atmosphere and biosphere. This global assessment however requires computation of a regional $\Delta R$ value for calibration to cater for studies based on a local scale. In this paper the marine reservoir effect is assessed for the south and east coast of South Africa using radiocarbon dating on pre-1950 marine shells of known age. The resultant $\Delta R$ values enable a more complete understanding of the marine reservoir effect along the south and east coastal zone of South Africa. Radiocarbon age determinations were conducted on 15 shell samples of known age and the results used to calculate regional marine reservoir correction values for the region. The east coast has a weighted mean $\Delta \mathrm{R}$ of $121 \pm 16^{14} \mathrm{C}$ years, while the south coast has a weighted mean $\Delta R$ of $187 \pm 18{ }^{14} \mathrm{C}$ years.

\section{KEYWORDS:}

Chronology, radiocarbon dating, marine reservoir effect, reservoir correction, South Africa 


\section{INTRODUCTION}

Quaternary palaeoenvironmental conditions in southern Africa remain poorly resolved due to the spatially and temporally fragmented nature of available evidence. The reconstruction of longer-term palaeoclimatic changes is, however, important because southern Africa is exposed to dynamics of both tropical and temperate climate regimes due to its latitudinal position (Carr, et al., 2006; Chase, et al. 2013). Southern Africa is influenced by a complex of tropical, subtropical and temperate climate systems arising from its geographical location and its position in relation to the Indian and Atlantic oceans. A deeper understanding of how climate and other features of the environment have varied during the late Quaternary is significant for a number of reasons, including the fact that the region represents a key locality in the archaeology of behaviourally modern humans and that the elucidation of the longerterm dynamics of its various climate controls is important to developing more reliable climate models. Indeed, the volume and quality of research into reconstruction of palaeoenvironmental conditions in the Quaternary of the region has increased markedly within the last decade in response to the recognition of its significance. Reconstructions are based on traditional proxies, such as pollen (e.g. Quick et al., 2016), diatoms (e.g. Kirsten and Meadows, 2012) and sedimentological parameters (e.g. Reinwarth et al. 2013) from wetland and lake sediments, as well as novel evidence, including a range of biological and chemical characteristics of rock hyrax middens (e.g. Chase et al., 2013). Other investigations are underway, including those carried out recently within the RAiN project (Regional Archives for Integrated iNvestigations), which is a multidisciplinary and multi-institutional collaboration that aims to explore evidence from terrestrial and offshore sediments of changing climate and associated environmental conditions during the late Quaternary in southern Africa (Haberzettl 2014). While these reconstructions have greatly improved understanding of environmental changes in the region during the Quaternary, the establishment of reliable chronologies, which are crucial for every palaeoenvironmental reconstruction, remain a key challenge for sedimentary sequences (Wündsch et al., 2016a). Several studies that link terrestrial and marine records to reconstruct palaeoclimates in the region have ensued, and therefore need to consider marine reservoir corrections (e.g. Wündsch et al., 2016a,b; Zhao et al., 2016).

Central to such studies is obtaining accurate age determination of the samples and, therefore, a reliable and robust chronology. This paper aims to approximate the marine reservoir effect for the southeast coastal region of South Africa as a step to better contextualizing results of the numerous late Quaternary palaeoenvironmental studies currently underway. $\Delta R$ is the regional marine reservoir offset from the global marine calibration curve and needs to be quantified in order to correct for the local conditions that affect diffusion of radiocarbon into the surface ocean (Stuiver et al., 1986). Reimer and Reimer (2001) remarked on the lack of reservoir correction data for most of Africa, and until now there have been very few such 
studies (Dewar et al., 2012; Southon et al. 2002; Wündsch et al., 2016a). Dewar et al. (2012) highlighted the need to conduct a regional reservoir correction study on the south coast of South Africa similar to the one they carried out for the west coast. The results reported here therefore respond to the need for additional $\Delta R$ estimates for the oceans around the African continent. The paper presents results of radiocarbon dating of 15 known-age (pre-1950) shell samples in order to derive a marine reservoir correction value for coastal regions of South Africa, for which hitherto there has been an inadequate database to enable radiocarbon age adjustment on sediments from coastal and marine sources. The samples yield results for two distinctive zones relating to the south and east coasts of South Africa and represent a sound data set on which to base $\Delta R$ values for a stretch of coastline extending over $1500 \mathrm{~km}$ between Richards Bay and Jeffrey's Bay.

\section{MARINE RESERVOIR EFFECT}

The marine reservoir correction values differ spatially and temporally due to differences in ocean currents, upwelling and latitudinal atmospheric variation (Ascough et al., 2005; 2006). The difference between the local reservoir age (which is specific to a region and determined using known-age marine samples) and the modelled global marine reservoir age is known as the $\Delta R$ value (Stuiver et al. 1986; Stuiver and Braziunas 1993; Stuiver, et al., 1998; Southon, et al., 2002) and is calculated as follows:

$\Delta \mathrm{R}(\mathrm{t})=\mathrm{Rs}(\mathrm{t})-\mathrm{Rg}(\mathrm{t})$

Where:

$\mathrm{Rs}(\mathrm{t})=$ regional reservoir age at a specific time period;

$\operatorname{Rg}(\mathrm{t})=$ modelled radiocarbon age of ocean surface water;

$\Delta R(t)=$ reservoir offset for a specific location at time $t$, usually determined using known-age marine samples.

The use of a marine reservoir correction value, $\Delta R$, is fundamental to the construction of archaeological and palaeoenvironmental chronologies in coastal or marine contexts. $\Delta R$ can be positive or negative for a specific location, and empirical studies of specific locations are required in order to determine the sign and the magnitude (Stuiver and Braziunas, 1993).

\section{METHODOLOGY}

There are three main methods used to determine $\Delta R$ values using marine samples, viz. using 'paired' shell/terrestrial samples (Wündsch et al., 2016a), known-age marine samples and onshore/offshore tephra isochrons (Ascough et al., 2005). Radiocarbon dating of 'paired' samples involves collecting charcoal/terrestrial and shell/marine samples from locations that 
are assumed to have adequate chronological integrity. The method employed in this paper bases $\Delta R$ calculations on the radiocarbon dating of marine shells of known age which have been collected pre-AD 1950 shortly after death and, while there are some constraints indicated by this method (Ascough et al., 2005), the advantage of using known-age marine samples is that it does not require comparison between terrestrial samples and marine shells (as is the case with paired samples), therefore reducing additional uncertainties introduced through dealing with two different sets of radiocarbon ages (UIm, 2002). Furthermore, there are no post-depositional issues or problems with bioturbation when using samples of known collection age (UIm, 2002). $\Delta R$ determination in this case relies, firstly, on the assumption that the date of original collection approximates the date of death of the organism and, secondly, on appropriately accurate museum curation and treatment prior to radiocarbon dating.

\section{Location of sample sites}

Only the west coast region of South Africa had been adequately studied in terms of marine reservoir corrections (Dewar et al. 2012). The choice of the southeast coastal region as a focus for this study was driven by the need to obtain accurate $\Delta R$ values due to the range of ongoing Quaternary palaeoenvironmental studies in southern Africa that are reliant on ${ }^{14} \mathrm{C}$ dating for chronology, more especially in relation to the ongoing RAiN project (Haberzettl et al., 2014). The general absence of limestone bedrock along the southeast coast is considered an advantage in this study as this reduces the likelihood of systematic error in the results through the incorporation of ${ }^{14} \mathrm{C}$-depleted material into the food chain. Carboniferous bedrocks have been shown to adjust the apparent radiocarbon age of the Hawaiian coast by up to +620 years (Dye, 1994). Therefore, non-filter feeding bivalves collected from areas where there is underlying limestone geology should be treated with caution (Reimer and Reimer, 2001). The search for a wide selection of bivalve material collected before AD 1950 led the authors to collections curated at the Natal Museum in Pietermaritzburg, South Africa, where there exists a substantial number of marine bivalve samples that meet the necessary criteria for the south and east coasts of South Africa (Table 1). Samples for radiocarbon dating were chosen in order to produce a relatively even spatial distribution along the coast based on their original collection localities (Figure 2).

Table 1: Locations of sample points used in this study (A-O). 'Acc no' is the Museum reference for the sample

\begin{tabular}{|c|c|c|c|c|c|c|c|}
\hline ID & $\begin{array}{c}\text { Acc } \\
\text { No }\end{array}$ & Family & Genus & Species & Locality & Latitude S & $\begin{array}{c}\text { Longitude } \\
\text { E }\end{array}$ \\
\hline A & 2349 & PTERIIDAE & Pinctada & nigra & Nonoti & $\begin{array}{c}29^{\circ} 18^{\prime} \\
46.5402^{\prime \prime}\end{array}$ & $\begin{array}{c}31^{\circ} 24^{\prime} \\
41.5974^{\prime \prime}\end{array}$ \\
\hline B & 3299 & PECTINIDAE & Pecten & sulcicostatus & $\begin{array}{c}\text { Algoa Bay, } \\
\text { off Bird } \\
\text { Island }\end{array}$ & $\begin{array}{c}33^{\circ} 58^{\prime} \\
1.1994^{\prime \prime}\end{array}$ & $\begin{array}{c}26^{\circ} 19^{\prime} \\
01.2000^{\prime \prime}\end{array}$ \\
\hline C & B7078 & VENERIDAE & Venus & verrucosa & Port Alfred & $33^{\circ} 36^{\prime}$ & $26^{\circ} 53^{\prime}$ \\
& & & & & $00.0000^{\prime \prime}$ & $59.9994^{\prime \prime}$ \\
\hline
\end{tabular}




\begin{tabular}{|c|c|c|c|c|c|c|c|}
\hline D & 2901 & LUCINIDAE & Lucina & carnosa & East London & $\begin{array}{c}33^{\circ} 00^{\prime} \\
33.5658^{\prime \prime}\end{array}$ & $\begin{array}{c}27^{\circ} 55^{\prime} \\
31.4862^{\prime \prime}\end{array}$ \\
\hline$E$ & 4520 & ARCIDAE & Arca & avellana & Kosi Bay & $\begin{array}{c}26^{\circ} 54^{\prime} \\
5.7594^{\prime \prime}\end{array}$ & $\begin{array}{c}32^{\circ} 52^{\prime} \\
00.5694^{\prime \prime}\end{array}$ \\
\hline $\mathrm{F}$ & 2800 & MERITRICINAE & Tivela & valae & Scottburgh & $\begin{array}{c}30^{\circ} 17^{\prime} \\
13.2966^{\prime \prime}\end{array}$ & $\begin{array}{c}30^{\circ} 45^{\prime} \\
36.4068^{\prime \prime}\end{array}$ \\
\hline G & 4494 & PECTINIDAE & Pecten & $\begin{array}{l}\text { benedictus cf } \\
\text { erythraeensis }\end{array}$ & Durban & $\begin{array}{c}29^{\circ} 50^{\prime} \\
55.9788^{\prime \prime}\end{array}$ & $\begin{array}{c}31^{\circ} 02^{\prime} \\
21.1626^{\prime \prime}\end{array}$ \\
\hline $\mathrm{H}$ & B7070 & MACTRIDAE & Mactra & glabrata & $\begin{array}{c}\text { Kabeljouws } \\
\text { River }\end{array}$ & $\begin{array}{c}34^{\circ} 00^{\prime} \\
12.4488^{\prime \prime}\end{array}$ & $\begin{array}{c}24^{\circ} 55^{\prime} \\
59.4186^{\prime \prime}\end{array}$ \\
\hline 1 & 4558 & ARCIDAE & Barbatia & foliata & $\begin{array}{l}\text { Shelley } \\
\text { Beach, } \\
\text { Izotsha }\end{array}$ & $\begin{array}{c}30^{\circ} 48^{\prime} \\
02.3070^{\prime \prime}\end{array}$ & $\begin{array}{c}30^{\circ} 24^{\prime} \\
51.3642^{\prime \prime}\end{array}$ \\
\hline $\mathrm{J}$ & A1034 & OSTREIDAE & Crassostrea & margaritacea & Umhlali & $\begin{array}{c}29^{\circ} 30^{\prime} \\
16.3794^{\prime \prime}\end{array}$ & $\begin{array}{c}31^{\circ} 14^{\prime} \\
24.1002^{\prime \prime}\end{array}$ \\
\hline K & B9981 & DONACIDAE & Donax & madagascariensis & Coffee Bay & $\begin{array}{c}31^{\circ} 58^{\prime} \\
57.1728^{\prime \prime}\end{array}$ & $\begin{array}{c}29^{\circ} 09^{\prime} \\
20.3178^{\prime \prime}\end{array}$ \\
\hline $\mathrm{L}$ & 2379 & PINNIDAE & Atrina & vexillum & Durban & $\begin{array}{c}29^{\circ} 50^{\prime} \\
47.6730^{\prime \prime}\end{array}$ & $\begin{array}{c}31^{\circ} 02^{\prime} \\
19.7736^{\prime \prime} \\
\end{array}$ \\
\hline$M$ & B7034 & PINNIDAE & Pinna & muricata & $\begin{array}{c}\text { Umgazi River } \\
\text { Mouth }\end{array}$ & $\begin{array}{c}31^{\circ} 40^{\prime} \\
59.9880^{\prime \prime}\end{array}$ & $\begin{array}{c}29^{\circ} 45^{\prime} \\
00.0000^{\prime \prime}\end{array}$ \\
\hline $\mathrm{N}$ & 9534 & SOLENIDAE & Solen & cylindraceus & Richards Bay & $\begin{array}{c}28^{\circ} 48^{\prime} \\
04.3734^{\prime \prime}\end{array}$ & $\begin{array}{c}32^{\circ} 03^{\prime} \\
37.4112^{\prime \prime}\end{array}$ \\
\hline $\mathrm{O}$ & 1896 & VENERIDAE & Dosinia & lupinus orbignyi & Algoa & $\begin{array}{c}33^{\circ} 49^{\prime} \\
36.3678^{\prime \prime}\end{array}$ & $\begin{array}{c}25^{\circ} 47^{\prime} \\
42.9462^{\prime \prime}\end{array}$ \\
\hline
\end{tabular}

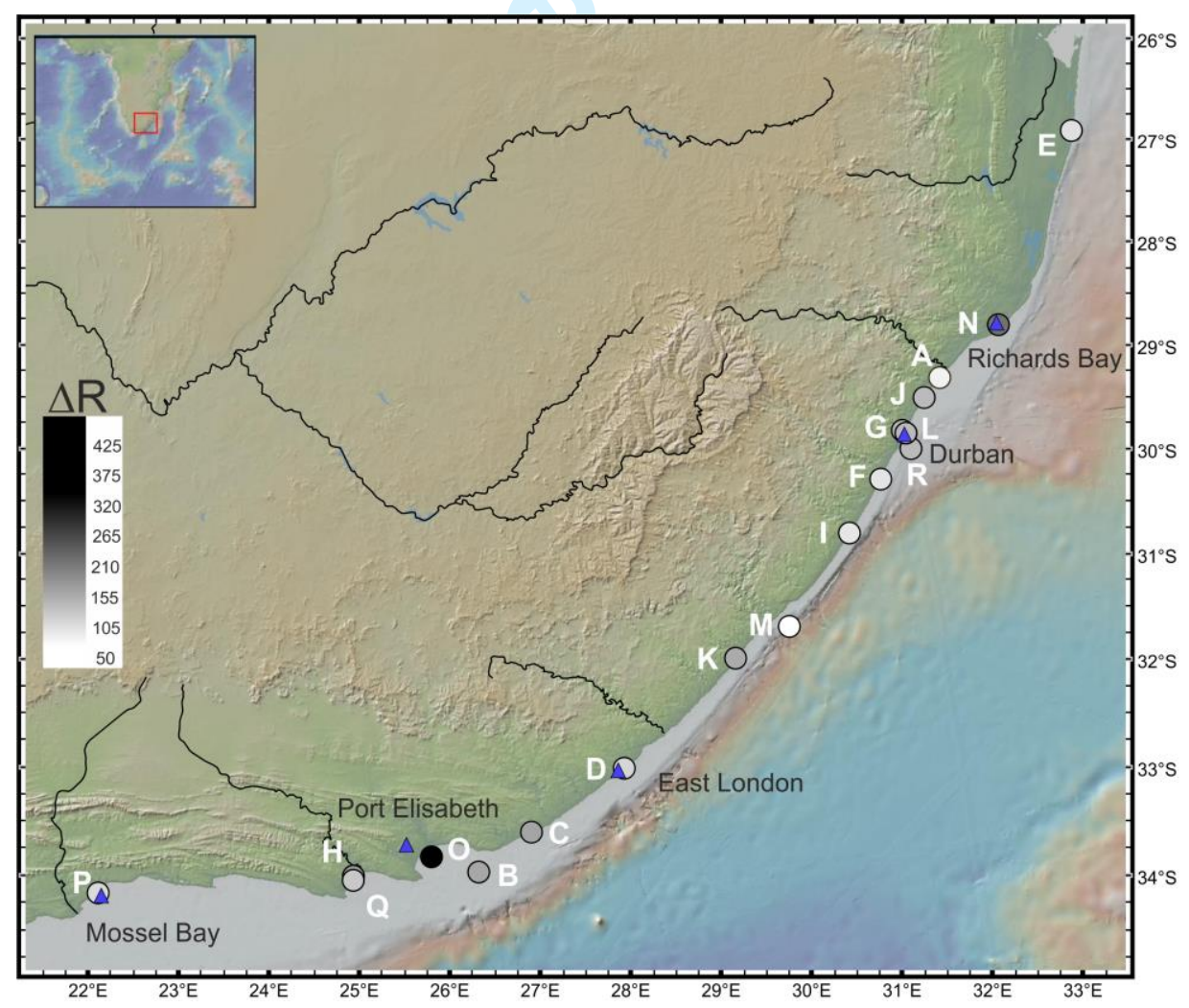

Figure 1: Locations of known-age marine shell samples A-O used in the analysis. Localities used in Wündsch et al. (2016a) are labelled P and Q, the Natal location for Southon et al. (2002) is labelled R, while Cape of Good Hope sample is off the map, located about $300 \mathrm{~km}$ 
west of Mossel Bay. Colour scheme shading from white to black correlates with increasing $\Delta R$ values. Descriptions for samples $(A-O)$ can be found in Table 1

\section{Species selection}

Marine molluscs offer the most appropriate material in providing the required estimate of $\Delta R$ because of their sedentary habits (Ascough et al., 2005). The challenge with migratory species is that they may represent carbon influences of several locations with different background

${ }^{14} \mathrm{C}$ content (Ascough et al., 2005). Hence, only, marine filter-feeding bivalves were selected as the most suitable object for this research as they are not migratory. The two pre-bomb samples from Wündsch et al. (2016) are gastropods (Ocenebra fenestrate from Mossel Bay is a carnivore and Drillia caffra from Jefferys Bay is a deposit feeder) but we have included them as they are in agreement with our filter-feeding samples. For the two samples from Southon et al. 2002, the Cape of Good Hope sample is a filter-feeding bivalve Venerupis corrugate but the feeding habitat of the bivalve Marcia paupercula from Natal is not known.

Harkness (1983) stated that a requirement for known age samples from museums is live collection, as well as thorough and accurate recording of locality and date of collection and storage. The Natal Museum, which is the source of samples used in this study, has robust standards of curation and record-keeping. Yoneda et al. (2000) highlight the importance of collecting material where there is evidence that the organism was collected live. For this study, only one sample (\#9534) contained unequivocal evidence of live collection, as the body tissues were preserved within the shell. Live collection can also reasonably be inferred from articulated bivalves and attachment of the resilium (Berkman and Forman, 1996), which was the case for sample \#9534. The other samples are assumed to have been collected a short time after death as the condition of the shells in question suggested that this was the case. All of the bivalves were unweathered and had both shells still in place, or available in the collection; this typically indicates collection at or shortly after death (Reimer and McCormac, 2002). Filter-feeding bivalve samples were collected for this research using only species that are known to reside predominantly in marine environments. Additional samples meeting the necessary criteria were not selected either because a) they represented the last remaining sample in the collection, b) it was the original sample used to describe/define the species type or c) were too small to be subsampled for radiocarbon dating. All samples had been collected in the 'pre-bomb' era, dating from 1905 to 1939, as documented in the museum record.

\section{Sample preparation}

Following sample selection from the Natal Museum Archives, the samples were mechanically prepared using a Dremel ${ }^{\circledR}$ micro-drilling tool. For all samples, preliminary external brushing was conducted to remove any visible surficial debris. Following this, a section of roughly 0.5 $\mathrm{cm} \times 0.5 \mathrm{~cm}$ of the outermost 2-3 growth increments was excavated from each sample and stored for shipping. Sample preparation and radiocarbon dating took place at the ${ }^{14} \mathrm{CHRONO}$ 
Centre in the Queen's University Belfast. The shell samples were washed in deionized water in an ultrasonic bath then air-dried and approximately $12 \mathrm{mg}$ of shell was placed in a septumsealed vial (Vacutainer). The samples were then etched with a quantity of $0.18 \mathrm{ml}$ of $1 \% \mathrm{HCl}$ for a $12 \mathrm{mg}$ shell sample to remove approximately $25 \%$ of the initial weight and then rinsed again with deionized water. Following the method of Santos et al. (2004), the vials were sealed, evacuated and then injected with $85 \%$ phosphoric acid $\left(\mathrm{H}_{3} \mathrm{PO}_{4}\right)$ and placed on a heating block at $60^{\circ} \mathrm{C}$ for $30 \mathrm{~min}$ to evolve carbon dioxide, which was cryogenically purified and transferred on the graphite line to a culture tube containing pre-baked iron. Following the method of Vogel et al. (1984), hydrogen gas was added and the tube was heated to $560^{\circ} \mathrm{C}$ for four hours. The graphite was then pressed in aluminium holders and analysed on a $0.5 \mathrm{MV}$ National Electrostatics Corporation Compact Accelerator Mass Spectrometer (AMS). The sample ${ }^{14} \mathrm{C} /{ }^{12} \mathrm{C}$ ratio was background corrected and normalised to the HOXII standard (SRM 4990C; National Institute of Standards and Technology). The ${ }^{14} \mathrm{C} /{ }^{12} \mathrm{C}$ ratio was corrected for isotopic fractionation using the AMS-measured $\delta^{13} \mathrm{C}$, which includes natural and machine fractionation (and therefore is not included in the text). The ${ }^{14} \mathrm{C}$ age and one standard deviation were calculated using the Libby half-life (5568 years) following the conventions of Stuiver and Polach (1977). 


\section{RESULTS AND DISCUSSION}

The $\Delta R$ values were calculated using the marine calibration curve (MARINE13, Reimer et al., 2013) and computed on the basis of the following equation

$\Delta \mathrm{R}=$ shell sample ${ }^{14} \mathrm{C}$ age - MARINE13 curve age

The uncertainty in $\Delta R$ is taken as the standard error in the ${ }^{14} \mathrm{C}$ age of the sample without including the calibration uncertainty that is taken into account by the calibration programs (Table 2).

Table 2: $\Delta R$ values as calculated for samples A-O

\begin{tabular}{|c|c|c|c|c|c|c|c|c|c|}
\hline ID & Accession \# & Genus & Species & Locality & Year collected (AD) & $\left({ }^{14} \mathrm{C}\right.$ age $\left.\mathrm{BP}\right)$ & $\begin{array}{l}\text { Marine13 } \\
\text { curve age }\end{array}$ & $\begin{array}{c}\Delta R \\
\left({ }^{14} \mathrm{C} \text { yrs }\right)\end{array}$ & $1 \sigma$ uncertainties \\
\hline A & 2349 & Pinctada & nigra & Nonoti & 1911 & 547 & 448 & 99 & \pm 26 \\
\hline B & 3299 & Pecten & sulcicostatus & Algoa Bay, off Bird Island & 1920 & 653 & 448 & 205 & \pm 27 \\
\hline $\mathbf{C}$ & $\mathrm{B} 7078$ & Venus & verrucosa & Port Alfred & 1928 & 660 & 452 & 208 & \pm 26 \\
\hline D & 2901 & Lucina & carnosa & East London & 1905 & 589 & 449 & 140 & \pm 26 \\
\hline $\mathbf{E}$ & 4520 & Arca & avellana & Kosi Bay & 1905 & 575 & 449 & 126 & \pm 29 \\
\hline $\mathbf{F}$ & 2800 & Tivela & valae & Scottburgh & 1913 & 568 & 448 & 120 & \pm 24 \\
\hline $\mathbf{G}$ & 4494 & Pecten & benedictus cf erythraeensis & Durban & 1939 & 580 & 459 & 121 & \pm 24 \\
\hline $\mathbf{H}$ & $\mathrm{B} 7070$ & Mactra & glabrata & Kabeljouws River & 1912 & 670 & 448 & 222 & \pm 26 \\
\hline $\mathbf{I}$ & 4558 & Barbatia & foliata & Shelley Beach, Izotsha & 1930 & 570 & 453 & 117 & \pm 25 \\
\hline $\mathbf{J}$ & A1034 & Crassostrea & margaritacea & Umhlali & 1941 & 641 & 461 & 180 & \pm 28 \\
\hline K & B9981 & Donax & madagascariensis & Coffee Bay & 1920 & 649 & 448 & 201 & \pm 25 \\
\hline $\mathbf{L}$ & 2379 & Atrina & vexillum & Durban & 1911 & 641 & 448 & 193 & \pm 28 \\
\hline $\mathbf{M}$ & B7034 & Pinna & muricata & Umgazi River Mouth & 1941 & 539 & 461 & 78 & \pm 26 \\
\hline $\mathbf{N}$ & 9534 & Solen & cylindrace us & Richards Bay & 1923 & 716 & 450 & 266 & \pm 26 \\
\hline 0 & 1896 & Dosinia & lupinus & Algoa & 1911 & 799 & 448 & 351 & \pm 28 \\
\hline
\end{tabular}


Considering all samples from this study (Table 2), the $\Delta R$ data span a range from $78 \pm 26$ to $351 \pm 28{ }^{14} \mathrm{C} y r s$; however the $\Delta R$ values do not pass a chi-squared test $\left(T^{\prime}=105.0, \chi_{i}{ }^{2}(0.05)=\right.$ 26.3). Overall, $\Delta R$ values in the south of East London are larger than those in the East. We therefore split the data into two sub-groups: South and East, split at East London, between Sample C and Sample D (Figure 1). According to Reimer and Reimer (2001), samples with $\Delta R$ values that are very markedly greater than the mean should be excluded from any regional mean calculation because they may not have been collected within a sufficiently short time following death. Sample $O(\Delta R=351 \pm 28)$, collected from Algoa Bay, has a $\Delta R$ value almost 100 years greater than many of the others (Table 2 ) and so exclusion was deemed appropriate. Exclusion of outlier sample $O$ from the south coast dataset results in a pass on the chi-squared test and produces a weighted mean $\Delta R$ value of $194 \pm 23$ (Table 3a) where the uncertainty is given as the standard error for predicated values (Russell et al. 2011). A similar exercise for the east coast samples identifies sample $N(266 \pm 28)$ as an outlier as well as samples $\mathrm{K}$ and $\mathrm{L}$ (Table $3 \mathrm{~b}$ ); their exclusion lowers the weighted mean $\Delta \mathrm{R}$ of the east coast samples to $119 \pm$ 15.

In order to test whether the $\Delta \mathrm{R}$ values of the south coast are larger than the east coast, we used a one-tailed t-test assuming unequal variances with a null hypothesis that they are the same. The hypothesis was disproved at $95 \%$ confidence limits with probability $=0.0135$ and only slightly less significant $(p=0.140)$ assuming equal variances. Using two-tailed t-tests, which imply the difference between the $\Delta R$ values of two coasts could be the opposite direction, results in $p=0.0269$ and $p=0.0281$ for unequal and equal variances, respectively. Therefore, according to the results outlined, $\Delta R$ values from the south and east coastal regions represent statistically significant sub-sets when evaluated with a t-test.

Table 3a, b: Geographical distribution of two populations of $\Delta R$ values from this study for the south and east coastal regions and correlating chi-tests with weighted means giving the uncertainty as the standard error of predicated values.

$3 a$

\begin{tabular}{|l|l|l|}
\hline South Sample Geographic ID & $\Delta R\left({ }^{14} \mathrm{C}\right.$ yrs $)$ & $\begin{array}{c}1 \sigma \\
\text { uncertainties }\end{array}$ \\
\hline B & 205 & 27 \\
\hline C & 208 & 26 \\
\hline H & 222 & 26 \\
\hline D & 140 & 26 \\
\hline \multicolumn{2}{|l}{} \\
\hline Chi-test for South (all samples except O) \\
\hline T' & $\chi_{i}(.05)$ & Passes? \\
\hline 5.93 & 7.8 & Yes \\
\hline \multicolumn{2}{|l}{} \\
\hline Weighted Mean & $194 \pm 23$ \\
\hline
\end{tabular}




\begin{tabular}{|c|c|c|}
\hline East Sample Geographic ID & $\Delta R\left({ }^{14} \mathrm{C}\right.$ yrs $)$ & $1 \sigma$ uncertainties \\
\hline A & 99 & 26 \\
\hline$E$ & 126 & 29 \\
\hline $\mathrm{F}$ & 120 & 24 \\
\hline G & 121 & 24 \\
\hline 1 & 117 & 25 \\
\hline $\mathrm{L}$ & 193 & 28 \\
\hline $\mathrm{K}$ & 201 & 25 \\
\hline M & 78 & 26 \\
\hline C & 208 & 26 \\
\hline J & 180 & 28 \\
\hline 2 & & \\
\hline \multicolumn{3}{|c|}{ Chi-test for East (all samples excluding $\mathrm{N}$ ) } \\
\hline $\mathrm{T}^{\prime}$ & $\chi_{i}(.05)$ & Passes? \\
\hline 21.91 & 15.5 & No \\
\hline \multicolumn{3}{|l|}{ Chi-test for East excluding N, L \& K } \\
\hline $\mathrm{T}^{\prime}$ & $x_{i}(.05)$ & Passes? \\
\hline 7.90 & 12.6 & Yes \\
\hline \multicolumn{3}{|c|}{$\mathrm{O}$} \\
\hline Weighted Mean & $119 \pm 15$ & \\
\hline
\end{tabular}

Prior to this study, only three $\Delta \mathrm{R}$ studies have been reported across the entire coastline of South Africa (Southon et al., 2002; Dewar et al., 2012; Wündsch et al., 2016) (Table 4), with the study by Dewar et al. (2002) confined to the west coast. The $\Delta R$ value determined for the east coast by Southon et al. (2002) was based on a marine shell collected in Kwa-Zulu Natal that yielded a $\Delta R$ value of $213 \pm 57$ (recalculated with MARINE13) (Sample R) which accords within the uncertainty with the $\Delta R$ values presented here for this eastern part of the South African coast. A pooled mean $\Delta \mathrm{R}$ for the East coast, inclusive of Sample $\mathrm{R}$ (Southon et al., 2002) and $\Delta R$ values from this study is $121 \pm 16$. For the south coast, Southon et al. (2002) documented a $\triangle R$ value of $224 \pm 51$ (recalculated with MARINE13) from a bivalve that was collected in AD 1820 from the Cape of Good Hope area, while Wündsch et al. (2016a) recorded $\Delta R$ values of $134 \pm 38$ (Sample $P$ ) and $161 \pm 38$ (Sample Q). If these previous values (Table 4) are analysed along with our south coast samples they are statistically the same $\left(T^{\prime}=9.12, \chi_{i}^{2}=12.6\right)$. We therefore include these previous measurements in our weighted mean for the south coast. The resultant mean $\Delta R$ for the south coast, inclusive of Sample $P$, $Q$ and $R$ is $187 \pm 18$. 
Table 4: $\Delta \mathrm{R}$ values from prior studies in the region

\begin{tabular}{|c|c|c|c|c|c|c|c|c|c|c|}
\hline & Reference & GENUS & $\begin{array}{c}\text { Species } \\
\text { name }\end{array}$ & $\begin{array}{c}\text { Common } \\
\text { name }\end{array}$ & Locality & Latitude & Longitude & $\mathbf{\Delta R}$ & $\begin{array}{c}\text { Standard } \\
\text { Error }\end{array}$ & $\begin{array}{c}\text { Sub- } \\
\text { region }\end{array}$ \\
\hline $\mathbf{P}$ & $\begin{array}{c}\text { Wündsch } \\
\text { et al., } \\
2016\end{array}$ & Muricidae & $\begin{array}{c}\text { Ocenebra } \\
\text { fenestrata }\end{array}$ & gastropod & $\begin{array}{c}\text { Mossel } \\
\text { Bay }\end{array}$ & $\begin{array}{c}39^{\circ} 09^{\prime} \\
28.8000^{\prime \prime}\end{array}$ & $\begin{array}{c}22^{\circ} 06^{\prime} \\
46.7994^{\prime \prime}\end{array}$ & 134 & 38 & south \\
\hline $\mathbf{Q}$ & $\begin{array}{c}\text { Wündsch } \\
\text { et al., } \\
2016\end{array}$ & Drillidae & $\begin{array}{c}\text { Drillia } \\
\text { caffra }\end{array}$ & gastropod & $\begin{array}{c}\text { Jeffrey's } \\
\text { Bay }\end{array}$ & $\begin{array}{c}34^{\circ} 02^{\prime} \\
34.7994^{\prime \prime}\end{array}$ & $\begin{array}{c}24^{\circ} 53^{\prime} \\
52.7994^{\prime \prime}\end{array}$ & 161 & 38 & south \\
\hline $\mathbf{R}$ & $\begin{array}{c}\text { Southon } \\
\text { et al., } \\
2002\end{array}$ & Tapes & $\begin{array}{c}\text { Marcia } \\
\text { paupercula }\end{array}$ & bivalve & $\begin{array}{c}\text { Near } \\
\text { Durban }\end{array}$ & $30^{\circ}$ & $31.1^{\circ}$ & $213 *$ & 57 & east \\
\hline $\mathbf{S}$ & $\begin{array}{c}\text { Southon } \\
\text { et al., } \\
2002\end{array}$ & Venerupis & corrugatus & bivalve & $\begin{array}{c}\text { Cape of } \\
\text { Good } \\
\text { Hope }\end{array}$ & $34.5^{\circ}$ & $18.6^{\circ}$ & $224^{*}$ & 51 & south \\
\hline
\end{tabular}

*Recalculated with Marine13

Both the east and south coast weighted mean $\Delta \mathrm{R}$ values are larger than the global ocean average $\left({ }^{14} \mathrm{C}\right.$ yrs by definition). However, our results indicate higher $\Delta \mathrm{R}$ values to the south, which suggests that waters with lower ${ }^{14} \mathrm{C}$ content compared to the northern region are found here. Immediately south of East London the continental shelf widens. As the continental shelf widens, the Agulhas Current, which flows southwestward along the shelf break, is forced away from the coast inducing divergence and cyclonic circulation inshore of the Agulhas Currents resulting in upwelling (Gill and Schumann, 1979). Applying the theory from Gill and Schumann (1979), Lutjeharms et al. (2000a) explain the presence of a semi-permanent upwelling cell (surface water cooler than $17^{\circ} \mathrm{C}$ ) inshore of the Agulhas Current, off Port Alfred $\left(33.5^{\circ} \mathrm{S}\right)$. Additionally, along the south coast, wind-driven upwelling combined with divergent flow driven by the Agulhas Current bring colder water onto the Agulhas Bank (Lutjeharms et al., 2000a). The colder upwelled water masses are sourced from radiocarbon depleted South West Indian Central waters from depths of $>500 \mathrm{~m}$, which have been found to mix with surface waters (Stuiver and Ostlund, 1983; Lutjeharms et al., 2000a). North of East London, the shelf is consistently narrow, and the northern Agulhas Current follows a stable trajectory, meandering less than $15 \mathrm{~km}$ from its mean path (Gründlingh, 1983). The narrow continental shelf and stable trajectory of the Agulhas Current inhibits the possibility for persistent upwelling of ${ }^{14} \mathrm{C}$ depleted waters, which may explain the lower $\Delta \mathrm{R}$ to the north.

In addition to providing insight into why there are two $\Delta \mathrm{R}$ populations, the regional oceanography may also explain why Sample N, near Richards Bay, has an older radiocarbon age than the other samples in the region. Lutjeharms et al. (1989) describe a persistent topographically-induced upwelling cell off Richards Bay due to a widening of the continental shelf, similar to the upwelling dynamics occurring near Port Alfred. However, contrary to Port Alfred whose upwelling waters are derived from the upper to middle layers of the South Indian Central Water (Lutjeharms et al., 2000a), there is no conclusive evidence of substantial amounts of deeper South Indian Ocean Central Waters being upwelled onto the shelf of the Natal Bight (Lutjeharms et al., 2000b), rather the circulation over most of the southern parts of the Natal Bight appear to be derived from Agulhas Current waters periodically encroaching 
onto the Bight, reaching as far as Durban, possibly explaining the outlier associated with Sample L.

\section{CONCLUSIONS}

Marine reservoir correction values for the south and east coastal regions of South Africa have hitherto been based on a very small sample size. This paper reports that the south coast has higher $\Delta R$ values than the east coast, and supplements those of Dewar et al. (2012) for the west coast. Further studies on the hydrography of the south and east coasts may help to cast further light on this finding, and increase both the volume and quality of reservoir correction data for the region. The determined $\Delta R$ values for the south and east coasts of South Africa indicate two distinctive geographical sub-regions. The east coast has a mean $\Delta R$ of $121 \pm 16$ years, while the south coast has a mean $\Delta R$ of $187 \pm 18$ years. Both these $\Delta R$ values are important for ongoing and future Late-Quaternary palaeoenvironmental studies on marine sediments, or marine-influenced sediments from the region.

\section{ACKNOWLEDGEMENTS}

This study was funded by the German Federal Ministry of Education and Research (BMBF). The investigations were conducted within the collaborative project "Regional Archives for Integrated Investigations" (RAIN), which is embedded in the international research programme: SPACES (Science Partnership for the Assessment of Complex Earth System Processes). We would also like to acknowledge the Palaeontological Scientific Trust (PAST), Dr. Dai Herbert from the Natal Museum, as well as the National Research Foundation (NRF) for their support in this research. We thank the anonymous reviewers for their constructive comments.

\section{REFERENCES}

Ascough PL, Cook G, Dugmore AJ. 2005. Methodological approaches to determining the marine radiocarbon reservoir effect. Progress in Physical Geography 4: 532-547.

Ascough PL, Cook GT, Church MJ, Dugmore AJ, Arge SV, McGovern TH. 2006. Variability in the North Atlantic marine radiocarbon reservoir effects at c. AD 1000. The Holocene 16(1): 131-136.

Berkman PA, Forman SL. 1996. Pre-bomb radiocarbon and the reservoir correction for calcareous marine species in the Southern Ocean. Geophysical Research Letters 23(4): 363-366.

Carr A, Thomas DS, Meadows ME, Chase B. 2006. Late Quaternary palaeoenvironments of the winter-rainfall zone of southern Africa: palynological and sedimentological evidence 
from the Agulhas Plain. Palaeogeography, Palaeoclimatology, Palaeoecology 239(1): 147-165.

Chase BM, Boom A, Carr AS, Meadows ME, Reimer PJ. 2013. Holocene climate change in the southernmost South Africa: rock hyrax middens record shifts in the southern westerlies. Quaternary Science Reviews 82: 199-205.

Deo JN, Stone JO. 2004. Building confidence in the shell: variations in the marine radiocarbon reservoir correction for the northwest coast for the past 3000 years. American Antiquity 69(4): 771-786.

Dewar G, Reimer P, Sealy J, Woodborne S. 2012. Late-Holocene marine radiocarbon reservoir correction for the west coast of South Africa. The Holocene 22(12): 1481-1489.

Dye T. 1994. Appparent ages of marine shells: Implications for archaeological dating in Hawaii. Radiocarbon 36(1): 51-57.

Gründlingh ML. 1983. On the course of the Agulhas Current. South African Geographical Journal 65: 49-57.

Harkness DD. 1983. The extent of natural ${ }^{14} \mathrm{C}$ deficiency in the coastal environment of the United Kingdom. PACT: Journal of the European Study Group on Physical, Chemical and Mathematical Techniques Applied to Archaeology 8: 351-364.

Haberzettl T, Baade J, Compton J, Daut G, Dupont L, Finch J, Frenzel P, Green A, Hahn A, Hebbeln D, Helmschrot J, Humphries M, Kasper T, Kirsten K, Mäusbacher R, Meadows M, Meschner S, Quick L, Schefuß E, Wündsch M, Zabel M. 2014. Paleoenvironmental investigations using a combination of terrestrial and marine sediments from South Africa - The RAIN (Regional Archives for Integrated iNvestigations) approach. Zbl. Geol. Paläont. Teil I, Jg. (Heft 1): 55-73.

Kirsten K, Meadows ME. 2012. Environmental changes along the southern Cape coast, South Africa during the last millennium: evidence from diatoms. Quaternary International 1: 279-282.

Lutjeharms JRE, Connell AD. 1989. The Natal Pulse and inshore counter currents of the South African east coast. South African Journal of Science 85: 533-535.

Lutjeharms JRE, Cooper J, Roberts M. 2000. Upwelling at the inshore edge of the Agulhas Current. Continental Shelf Research 20(7): 737-61. 
Quick L, Meadows, ME, Bateman M, Kirsten K, Mäusbacher R, Haberzettl T, Chase B. 2016. Vegetation and climate dynamics during the last glacial period in the fynbosafrotemperate forest ecotone, southern Cape, South Africa. Quaternary International 404(B): 136-149.

Reimer PJ, McCormac FG. 2002. Marine radiocarbon reservoir corrections for the Mediterranean and Aegean Seas. Radiocarbon 44(1): 159-166.

Reimer PJ, Reimer RW. 2001. A marine reservoir correction database and on-line interface. Radiocarbon 43(2A): 461-463.

Reimer PJ, Bard E, Bayliss A. 2013. INTCAL13 and MARINE13 radiocarbon age calibration curves 0-50,000 years cal BP. Radiocarbon 55(4): 1869-1887.

Reinwarth B, Franz S, Baade J, Haberzettl, T, Kasper, T, Daut, G, Helmschrot J, Kirsten K, Quick L, Meadows M, Mäusbacher R. 2013. A 700-year record on the effects of climate and human impact on the southern Cape coast inferred from lake sediments of Eilandvlei, Wilderness Embayment, South Africa. Geografiska Annaler: Series A, Physical Geography 95: 345-360.

Russell N, Cook GT, Ascough P, Barrett JH, Dugmore A. 2011. Species specific marine radiocarbon reservoir effect: a comparison of $\Delta R$ values between Patella vulgata (limpet) shell carbonate and Gadus morhua (Atlantic cod) bone collagen: Journal of Archaeological Science 38: 1008-1015.

Santos GM, Southon JR, Druffel-Rodriguez KC, Griffin S, Mazon M. 2004. Magnesium perchlorate as an alternative water trap in AMS graphite sample preparation: A report on sample preparation at KCCAMS at the University of California, Irvine. Radiocarbon 46: 165-173.

Southon J, Kashgarian M, Fontugne M, Metivier B, Yim WW-S. 2002. Marine reservoir corrections for the Indian Ocean and Southeast Asia. Radiocarbon 44(1): 67-180.

Stuiver M, Braziunas TF. 1993. Modelling atmospheric ${ }^{14} \mathrm{C}$ influences and ${ }^{14} \mathrm{C}$ ages of marine samples to 10,000 BC. Radiocarbon 35(1): 137-189.

Stuiver M, Pearson, GW, Braziunas TF. 1986. Radiocarbon age calibration of marine samples back to 9000 cal yr BP. Radiocarbon 28(2B): 980-1021.

Stuiver M, Reimer PJ, Braziunas TF. 1998. High-precision radiocarbon age calibration for terrestrial and marine samples. Radiocarbon 40(3): 1127-1151. 
Stuiver M, Ostlund HG. 1983. GEOSECS Indian Ocean and Mediterranean radiocarbon. Radiocarbon 25(1): 1-29.

Stuiver M, Polach HA. 1977. Discussion: reporting of 14 C data. Radiocarbon 19(3): 355-363.

Ulm S. 2002. Marine and estuarine reservoir effects in central Queensland, Australia: determination of $\Delta R$ values. Geoarchaeology 17: 319-348.

Vogel JS, Southon JR, Nelson DE, Brown TA. 1984. Performance of Catalytically Condensed Carbon for use in Accelerator Mass-Spectrometry. Nuclear Instruments and Methods in Physics Research Section B-Beam Interactions with Materials and Atoms 5(2): 289293.

Wündsch M, Haberzettl T, Meadows ME, Kirsten KL, Kasper T, Baade J, Daut G, Stoner JS, Mäusbacher R. 2016.a. The impact of changing reservoir effects on the 14C chronology of a Holocene sediment record from South Africa. Quaternary Geochronology 36: 148160.

Wündsch M, Haberzettl T, Kirsten K, Kasper T, Zabel M, Dietze E, Baade J, Daut G, Meschner S, Meadows M, Mäusbacher R. 2016.b. Sea level and climate change at the southern cape coast, South Africa, during the past 4.2 kyr. Palaeogeography, Palaeoclimatology, Palaeoecology 446: 295-307.

Yoneda M, Uno H, Shibata Y, Suzuki R, Kumamoto Y, Yoshida K, Sasaki T, Suzuki A, Kawahata $H$. 2007. Radiocarbon marine reservoir ages in the western Pacific estimated by prebomb molluscan shells. Nuclear Instruments and Method in Physics Research 259(B): 432-437.

Zhao Q, Dupont L, Schefuss E, Hahn A, Meadows ME, Wefer G. 2016. Holocene vegetation and climate variability between winter and summer rainfall zones of South Africa. The Holocene 26: 843-857.

\section{LIST OF FIGURES}

Figure 1: Locations of known-age marine shell samples A-O used in the analysis. Localities used in Wündsch et al. (2016a) are labelled P and Q, the Natal location for Southon et al. (2002) is labelled R, while Cape of Good Hope sample is off the map, located about $300 \mathrm{~km}$ west of Mossel Bay. Colour scheme shading from white to black correlates with increasing $\Delta R$ values. Descriptions for samples (A-O) can be found in Table 1 


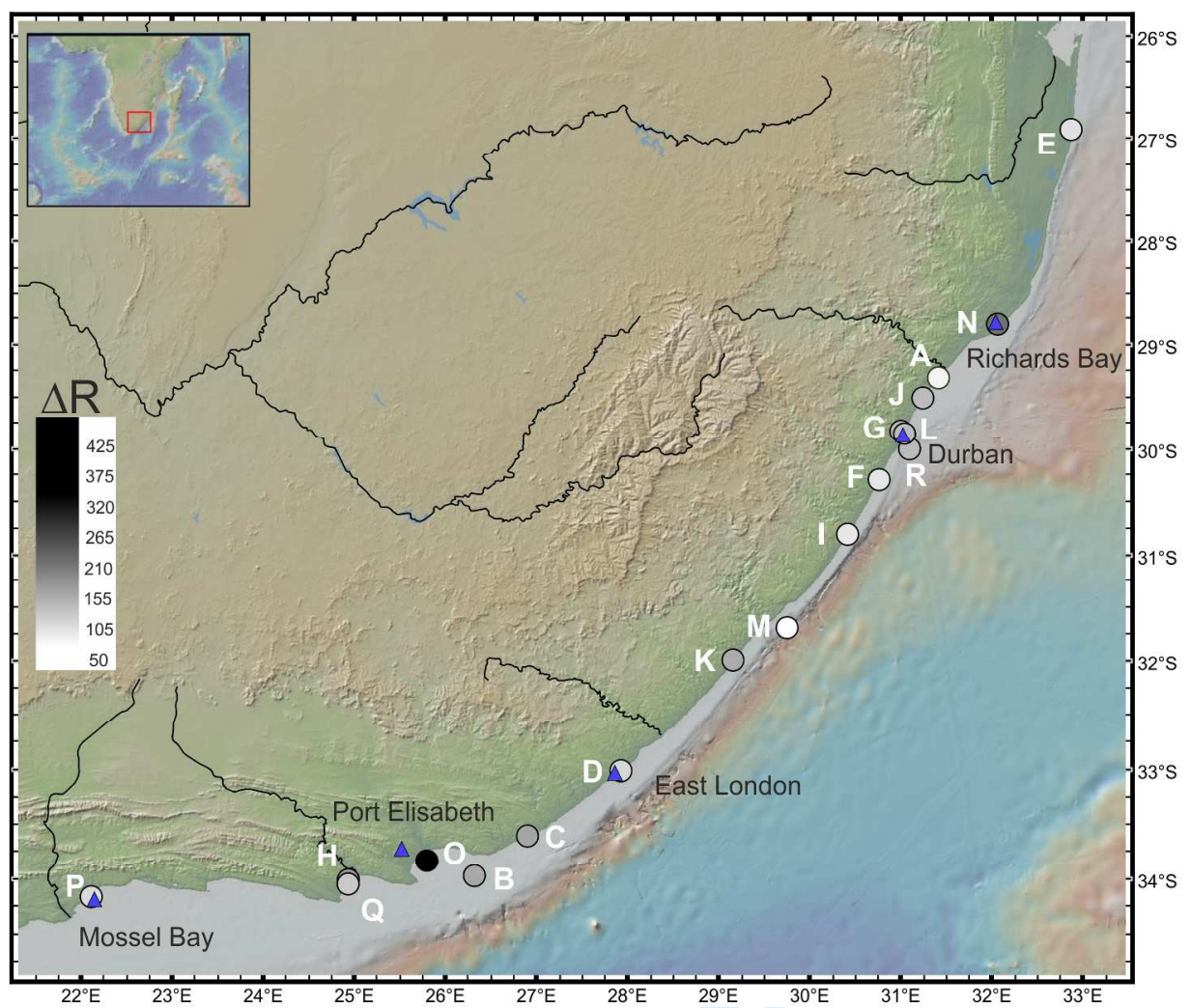

Figure 1: Locations of known-age marine shell samples A-O used in the analysis. Localities used in Wündsch et al. (2016a) are labelled P and Q, the Natal location for Southon et al. (2002) is labelled R, while Cape of Good Hope sample is off the map, located about $300 \mathrm{~km}$ west of Mossel Bay. Colour scheme shading from white to black correlates with increasing $\Delta R$ values. Descriptions for samples (A-O) can be found in Table 1 